\title{
THE NEXT LEGISLATION ON INDUSTRIAL DISPUTES IN MASSACHUSETTS
}

\author{
By Robert Luce, EsQ., \\ Boston, Mass.
}

Throughout most of the world existing laws for the control of industrial warfare are accomplishing relatively small results. For example, in Massachusetts in the five years 1904 to 1908 , inclusive, there were 950 strikes, affecting 3,196 establishments, involving 94,923 strikers, throwing out of work 45,535 other employees, thus causing loss of wages all told to 140,458 workers, who lost approximately $5,353,839$ working days, which at the average wage-rate meant a loss to the employees of about $\$ 8,500$,ooo, with a loss to the employers of corresponding profits, to say nothing of waste through idle plants, interest on idle capital, loss of customers, and damage to allied industries. About twenty-four per cent of the strikes wholly succeeded; thirteen per cent succeeded in part ; five per cent were reported as "indefinite or unsettled," and fifty-eight per cent failed; two-fifths succeeded wholly or in part; three-fifths failed.

In Austria in 1906 there were I,083 strikes, affecting 6,049 establishments. In Belgium in the five years covered by the report of 1907 there were 474 strikes, affecting $\mathrm{I}, 28 \mathrm{I}$ establishments. In France in 1906 there were I,309 strikes, affecting 19,637 establishments. In Germany in the same year there were 3,328 strikes, affecting $\mathbf{I} 6,246$ establishments; in Great Britain, 486 strikes and lockouts. Russia had 1,765 strikes in ten years. Arbitration as a remedy has not met expectations. Of the 547 strikes in Massachusetts in the three years ending with 1908 , only twenty-three were settled by arbitration, four per cent, one in twenty-five. Of very close to I4,000 strikes in the United States in five years, less than two per cent were so settled. Yet long after the agitation for arbitration began in the middle of the last century, enthusiastic reformers thought it the panacea for labor troubles. When in England they began working for it, they seem to have thought it the idea embodied in the Conseils de Prud 'hommes, the industrial tribunals created by Napoleon when at the height of his power. These (407) 
have indeed for a hundred years served France admirably, but their success has been due to the reason that they concern themselves only with shop disputes where the facts can be known. It was supposed their principle was put into Lord St. Leonard's Act of 1867 and the Arbitration Act of 1872. Under these two laws, however, not a single application was ever made, and in 1896 the present plan was substituted, being a mild measure for voluntary conciliation and arbitration. This brought about in the next seven years the settlement by arbitration of an average of twenty-two cases a year, about three per cent of all the strikes and lockouts.

In this country New Jersey and Pennsylvania led the way, being followed by Massachusetts in 1886 with the creation of its present Board of Conciliation and Arbitration, largely due to the interest of Senator W. L. Douglass, afterward Governor. Great hopes were entertained of it. Yet it has not ended strikes, has not even conspicuously lessened industrial warfare.

The reason is not far to seek. There are two classes of disputes in industry, one relating to things that have happened, one relating to things that are to come. By far the greater number of strikes concern things that are to come, such as wages and hours. Arbitration is all right when the past is concerned, almost always sure to fail when the future is concerned. Arbitration means reference to an umpire with an obligation to be bound by the decision, a voluntary obligation here, a compulsory obligation in New Zealand. A decision on the basis of known facts will be accepted as it is in the case of lawsuits. There one party is right and the other wrong. But when the future is in issue, both parties may be right. The employer, for instance, may be within his rights when he says he cannot afford to pay more than two dollars a day; the employee may be equally justified in saying he cannot afford to take less than two dollars and fifty cents. The solution must be a bargain, not a decision, for a decision implies a basis of known facts. Men will not consent that third parties shall make bargains for them. Furthermore, in the case of a sympathetic strike there is literally "nothing to arbitrate." Voluntary arbitration, then, should be retained for cases such as the interpretation of a contract, where the facts can be ascertained. Many shop agreements now provide for arbitration of this sort. But for disputes relating to the future the remedy is to be sought elsewhere. 
Compulsory arbitration, as attempted in Australasia, will in all probability not be tried here in our time, for two reasons: first, it is contrary to American conceptions of individual liberty; and secondly, it is based on an economic fallacy-the notion that wages can be fixed by law, for that is what it amounts to. That was attempted nearly six hundred years ago, by the Statutes of Laborers, after the Black Death carried off half the population of England. It has been elsewhere tried since, always with failure and disaster in its train. No judge, no legislature is competent to prescribe what an employer shall pay a workman. No employer will consent to wages that spell ruin; no workman will accept wages less than he can earn elsewhere. Compulsory arbitration, therefore, is not the thing here to be tried.

Study of the problem in the light of experience brings into relief two of its phases: First, it becomes clear that remedies so far tried have been in large measure spoiled by the fact that they were applied after the disputants had become embroiled, after war had been declared, after the battle was on, when passion had embittered the situation, when pride had made conference useless and concession impossible. These remedies mean the pound of cure instead of the ounce of prevention.

Secondly, it becomes clear that there are three parties to every industrial dispute, the public being a third party. When Charles Francis Adams began urging this seven or eight years ago, he was met even by men of intelligence with the argument that only employer and employee were concerned, and that it was the business of nobody else. For the state to interfere in a private quarrel, was thought preposterous. Now men are coming to see that every quarrel affecting commerce or industry, involves the prosperity of the community, and that neither the wage-earner nor the wagegiver has a right to injure his fellows in order to better his own condition unfairly. It is now seen that every strike injures the public; some strikes do serious injury. For instance, a despatch to the Boston "Herald," of February 7th, said that the expense of the Ludlow strike to the little town amounted to $\$ 8,5 \circ 0$, and taxes would be raised. "The merchants have felt it severely and it will take many of them some time to get on their feet again."

The Lynn lasters' strike of October, Igo8, starting because twenty men assemblers were replaced by twelve girls, threw out of 
work $12,76 \mathrm{I}$ men and women employed in sixty-seven establishments, and lost to Lynn the making of $1,136,344$ pairs of shoes that would have had a selling value of $\$ 1,7$ I5,766. It at any rate hastened the departure of two factories, one of which went out of the state, and it has been announced that the factory in which the trouble started will this summer be removed.

Late in 1906 these considerations set W. L. Mackenzie King a thinking. He was a young, earnest, vigorous, thoughtful Canadian, in the service of the government, sent in the course of duty to the province of Alberta to see if he could settle a big coal strike. He found employer and employee equally obdurate. Meanwhile the people froze. He came back convinced of the two things I have emphasized-that the public as a third party has the right to compel measures likely to secure industrial peace, and that they should be resorted to before rather than after the outbreak of hostilities. So there came about the passage of the Canadian law for the investigation of industrial disputes-to-day the most promising remedy for the evils of industrial warfare.

The Canadian Act requires that in the event of a dispute arising in any industry known as a public utility, it shall be illegal to resort to a strike or lockout until the matters in dispute have been laid before a board of investigation. Such a board is appointed by the Minister of Labour on the application of either party. One of its members is named by the employer; one is named by the employees; these two choose a third, or on their failure to agree, he is named by the minister. The proceedings and final report are at once published extensively, for their influence on public opinion. After the report, and not until then, the employer may lock out or the employees may strike, if either declines to accept the advice of the board.

Harris Weinstock in January of this year made to the Governor of California his report of fifteen months of investigation of labor laws and conditions in Europe and Australasia, as a special labor commissioner. He found that voluntary arbitration was largely a failure the world over, and concluded that compulsory arbitration would not fit the conditions of California. Before learning of the Canadian law he had reached the opinion that "an important stride would be made in the direction of industrial peace, if legislation was created calling for a public inquiry in labor disputes before 
they had reached the serious stage of strike or lockout." Thus quite independently he hit upon the principle already applied in Canada. He has advised the passage of a law along precisely the same lines, restricted to public utilities.

Dr. Victor S. Clark has made for the United States Bureau of Labor two thorough and conservative reports on the Canadian law, one appearing in the Bulletin for May, 1908, and the other in that for January, I9ro. In the conclusion of the later report he says: "Under the conditions for which it was devised, the Canadian law, in spite of some setbacks, is useful legislation, and it promises more for the future than most measures-perhaps more than any other measure-for promoting industrial peace by government intervention."

Observers watching the actual results of the principle as applied in Canada have sought its application elsewhere. It has been copied in the Transvaal. In the United States attention was called to it by articles of strong praise by President Charles W. Eliot. Campaigns for its introduction are under way in several American states. Those active in the fight feel confident of ultimate victory; for, thanks to Canada, they have at command the arguments of experience. "The proof of the pudding is in the eating."

In the first three years of the operation of the Canadian law (March, I907-March, I910) eighty-two applications were received for the establishment of boards of conciliation and investigation, as a result of which seventy-four boards were established. In sixtyeight out of the seventy-four cases referred for investigation, the inquiry resulted either in a direct agreement between the parties, or in such an improvement of relations as led to the settlement of the dispute. In two of the cases where reference under the act was not successful in either averting or terminating a cessation of work, the men finally returned on the terms recommended by the board.

In the ten years prior to the enactment of the Canadian law there were Ioo strikes in public utilities-an average of ten a year. In the three years after its enactment the average fell to two a year. In every single case where the question was one of wages, hours, or conditions of employment, investigation prevented strike or lockout. Altogether nearly 60,000 employees were directly concerned in the disputes settled. Had strikes not been thus avoided, it is estimated they would have lost $\$ 3,500,000$ in wages. 
Compulsory investigation secures such remarkable results because it is based on common sense and human nature. Notice of grievance acquaints the other side and gives chance of concession before the parties get embroiled. Calm inquiry discloses with some accuracy the points in dispute, ignorance or misunderstanding of which has led to many a costly strike. It nips trouble in the bud. As things go now, once hostilities have begun, false pride forbids either party to retreat. Then original causes are forgotten in the new grievances that friction levelops. The new plan prevents hasty, rash action, gives chance for inflamed passions to cool, for angry words to be forgotten. Most important of all, it brings the disputants face to face, lets them talk it out, gives them a chance to be heard. Experience in Canada shows that with the disputants on opposite sides of the same table, with no lawyers present, with the reporters excluded, and with dispassionate investigators directing the conference, an atmosphere of good will is soon created, suspicions are allayed, concessions are encouraged. After the investigators have given their advice, if it is accepted, there is no more resentment, malice, spite, no consciousness of humiliating defeat by overpowering strength, no desire for vengeance.

The great value of the law lies in its providing a negotiating rather than a deciding body, thus preventing strikes by bringing the parties to a voluntary settlement. Its real worth does not lie in holding over them any sort of a club in the nature of a penalty, whether moral or otherwise. In practice the penalties have been found unimportant. Most workmen and most employers want to be law-abiding citizens. If the state says they must not strike or lock out until after investigation, most of them will comply regardless of penalty. The others, few in number, would probably evade any law that could be written. Employers can evade this law by shutting down on some pretext. Employees can evade by the runaway strike, vanishing one at a time. The answer is that in Canada as a matter of fact they do not.

In this respect as in other particulars public opinion largely controls the situation. Fear of it incites both sides to comply with the spirit of the law. Fear of it keeps either side from asking investigation of an unjust position. Fear of it impels each party to make reasonable concessions. Publicity compels fair play.

The Dominion Trades and Labor Congress, the most influential 
labor body in Canada, is probably the best exponent of labor sentiment throughout the Dominion, and carries most weight with political parties. Its president is a member of Parliament. The following report by the executive officers was made to the congress at the Winnipeg session:

"The Trades Dispute Investigation Act, I907. Your executive, after careful consideration, gave its hearty endorsation to the principles of the bill. Organized labor does not want to strike or enforce its demands if the consideration of them can be attained without recourse to this remedy. The strike has been our last resort, and as the bill continued our right to strike, but assured a fair hearing of the demands of the workers, there was nothing to do but to give our support to it. Nor is organized labor blind to the fact that in every great industrial struggle the public have a large interest as well in the result as in the means adopted to reach that result. The least the public are entitled to is a knowledge of the merits of the dispute. This knowledge will be given to them under the procedure outlined in the bill. Your executive believes it will be a happy day when every labor dispute can be settled by the parties meeting together in the presence of an impartial tribunal to discuss their differences. Our great difficulty in the past has been that we could not get a hearing."

After debate in which twenty of the delegates, including executive officers, took part, the following resolution was adopted by a vote of eighty-one to nineteen:

WhEREAS, Organized labor has from time to time expressed its disapproval of strikes except as a last resort in industrial disputes; and, whereas, particularly in disputes in connection with public utilities the public have rights that must be respected and considered; and, whereas, the Lemieux Bill is designed to avoid strikes and lockouts, in connection with industrial disputes, in certain public tutilities, until such time as the merits of the dispute are publicly investigated; and, whereas, organized labor always courts investigation of its grievances by reason of the justice of its claims and its desire to be fair;

Resolved. That this Trades and Labor Congress of Canada hereby express its approval of the principles of the Lemieux Bill as being in consonance with the oft-expressed attitude of organized labor in favor of investigation and conciliation.

A proposal to have the act amended so as to exempt the employees of both steam and electric railways was voted down. The 
big organizations of railroad men in Canada were at first sceptical about the law or openly hostile. Now the railroad men are practically a unit in its support, doubters not being plenty enough to take into account. Indeed the only serious opposition to the law that remains among those with practical experience, is found on the part of some of the mining unions so dominated by socialistic beliefs as to be hostile to any remedies not based on the principles of socialism.

Another labor organization, the National Trades and Labor Congress, heard this from its Executive Committee at Quebec after the law had been in force almost a year and a half:

"No legislative enactment since confederation has had so immediate and far-reaching an influence upon organized labor in Canada as the Industrial Disputes Investigation Act of 1907, known as the Lemieux law. From the official reports of investigations of disputes under the act, from its enactment March 22, 1907, to the present time, the majority of the unions involved have expressed satisfaction with the award, and as a result, the principle of compromise, so powerful a factor in society as it is constituted to-day, has been recognized, the duration of strikes has been reduced, large strike funds have become less important as a fighting weapon, and outside interference has not only become unnecessary, but even a cause of loss of public sympathy."

The Secretaire General of the Parti Ouvrier du Canada writes:

"The law is certainly a good one and has proved so in many cases, because it gives the workingman the opportunity of bringing his complaints and his real situation before the general public. Furthermore, the law has recognized the official existence of labor organizations, and has prevented many strikes and lockouts. I am one of those who really believe that this law ought to be made compulsory to all employments. If it is a good law for some industries, it ought to be good also for all."

The Grand President of the Canadian Brotherhood of Railroad Employees writes:

"The law as it stands is in my opinion a good one. The only change I could suggest, which would be of advantage, would be to widen its scope to take in all classes of employment."

The Grand Secretary of the Provincial Workmen's Association writes: 
"I think it is wise legislation. I have had some little experience with it all over this province, and the more $I$ see of it, the more I am impressed with its fairness to both parties of the dispute. I do not think it would hurt the parties to any dispute to have public investigation into the cause of the dispute."

On the advice of the Canadian Minister of Labour and a majority of the many Canadians with whom correspondence was instituted, we drew the bill for Massachusetts to apply to all industries, instead of confining it to public utilities as in Canada. After test of it there for some months the Dominion Trades and Labor Congress, the most influential labor body in Canada, voted by fifty-nine to twenty-two to ask that it be extended to cover all industries. The Canadian Federation of Labor at its convention last fall passed a similar vote, and in accordance therewith a delegation headed by the president of the Federation, laid the request before the Minister of Labour, who expressed his sympathy with the idea. His own view was that a beginning in the way of extension might be made by including the building trades within the operation of the act, these trades being, as he believed, to a large degree within the meaning of the term "public utilities." It was his purpose to extend the law into other occupations as fast as feasible.

It has been suggested that in some of our states it might not be constitutional to have the law apply to all industries, though undoubtedly valid for public utilities. The best authority sees no difficulty on this score. The bill does not propose to make it unlawful for an employer to discharge a man or for an employee to quit work. What it does do is to declare the purpose of lockout or strike unlawful, prior to investigation. Our courts have held that an innocent act may be made unlawful because of its purpose. A strike is concerted action with a purpose, and concerted action may make an innocent act unlawful. There is no reasonable doubt that under the police power we may prohibit concerted action, if its result would be to disturb the public peace or injure the public welfare, or indeed could prohibit individual action if it threatened such result.

It was not the purpose of the bill drawn for Massachusetts to abolish the State Board of Conciliation and Arbitration. It was meant simply to add the function of compulsory "investigation." Another bill, introduced on the petition of President Eliot and 
George $B$. Hugo would in practice have resulted in the speedy abolition of the Board of Conciliation and Arbitration, and such was understood to be the object of its backers. This did not seem to some of us prudent or desirable. Arbitration is occasionally available and ought to be retained. Furthermore many shops in Massachusetts are now working under agreements to refer disputes to the state board for arbitration and it would be a pity to interfere with this practice. So our bill would keep the state board at the command of those who are willing to arbitrate.

The Canadian law creates a special investigating board for each dispute, partly because Canada is so large that a central body could not handle everything from Halifax to Vancouver. A permanent board would be more economical, its members would have the advantage of experience, and in more or less cases it would be acceptable. To combine the merits of each method, we provided that the disputants might have a special board or use the state board, as they should elect.

Organized labor in Canada was apprehensive that under their law as written, employers could evade the spirit of it by massing strike breakers in anticipation of an unfavorable opinion from the investigating board. So the Dominion Trades and Labor Congress asked certain changes in phraseology to meet this, and they were incorporated in the Massachusetts bill. Otherwise our bill followed the Canadian law as it stood, with some changes to conform to Massachusetts practice. It was passed on by the Canadian Minister of Labour, and only changes meeting his approval were made.

Our experience in the first attempt to enact the principle of the Canadian law in Massachusetts, may be instructive. At one time it looked as if the measure would pass without serious opposition. Then both employers and employees began to magnify dangers to selfish interests. The leaders of the unions woke up to the fact that the bill meant to them the loss of the power given by the sudden blow. They swiftly spread throughout the ranks the belief that strikes were to be made crimes. Impassioned orators crowded the committee room with denunciations of this treacherous plot to throttle organized labor. Most careful explanations of the law fell on deaf ears. It was in vain that the hearty words of approval written by Canadian labor leaders were read again and again. It was of no use that proof was brought of the desire of organized (4I6) 
labor in Canada that the law shall be extended to cover all industries. The workers became convinced that their cause was attacked. and they refused to believe that men not of their numbers could really have their interests at heart.

On the other hand, certain employers at the head of large nonunion shops, content with their own success in warding off what they deem the aggressions of labor, discovered a chance that the law would interfere with their discipline and might compel them to negotiate with their workmen. Unfamiliar with the merits of collective bargaining, exaggerating its defects, accustomed to exercise the authority of dictators, they resented the suggestion of any measure of control in the public interest. One of them saw in a bill meant to protect and relieve and help the employer just as much as the employee, one more handicap on Massachusetts industries in their competition with those of other states. Another saw in it the opportunity for one manufacturer to pry into the books and learn the trade secrets of his competitor. Still another was apprehensive lest the law might foment labor troubles and incite his employees to make demands, on the ground that they had nothing to lose and a chance to gain. Still others argued that as they were themselves getting along all right with their men, it would be better to let well enough alone.

The proofs from Canada that their apprehensions were bugaboos, that the law had not in fact stirred up strife, that trade secrets had not been disclosed, that all parties had distinctly gained, that peace had been encouraged and strife lessened-all fell on ears just as tightly closed to the lessons of experience as those of the union leaders. So it became clear that no speedy acceptance of the truth was possible, but that one more long, hard and costly campaign of education must be carried through before common sense can prevail.

Proud as one may be of the governmental processes of the United States, such an episode can hardly fail to make one uncertain as to whether they are after all distinctly superior to the system of ministerial responsibility to which England and her colonies are accustomed. In Canada a small group of men-the ministry-became convinced that $\mathrm{Mr}$. King was right and that his solution of the strike problem was sane and practicable. They took the responsibility for putting it into law and the issue justified them. Once 
well tested, employers and employees alike approved and accepted it. Here, on the other hand, we must convince employers and employees and public - thousands on thousands of persons-before a test can be made. We must conquer a myriad of fears and alarms, a multitude of misconceptions. While other countries act, we talk.

Doctor Clark is of the opinion that the adoption of a statute similar to the Canadian law in any state or by the United States Government, whether desirable or not, is likely to be opposed by organized labor, and probably could be secured only after some industrial crisis profoundly affecting public opinion had centered popular attention upon the question of strike prevention. This may be true, and yet it is of importance that those who already appreciate the need of action shall without waiting for emergency take every opportunity to encourage accurate and rational discussion of the problem. It may take time, but in the end the justice and the expediency of industrial peace will alike appeal to those who create the opinion on which law is based. Peace is to the interest of all parties, peace with honor, and that is what compulsory investigation gives. It promises wage-earners a chance for fair play. It promises the employer security. It means for industry what the tribunal at the Hague means for the nations. 